\title{
A Market Scheduling for New Normal Logistics in the Wake of Corona Virus Diseases-19 in Bandung City
}

\author{
Carles Sitompul ${ }^{1}$, Paulina Kus Ariningsih ${ }^{2}$, Fran Setiawan ${ }^{3}$ \\ 1,2,3) Fakultas Teknologi Industri, Jurusan Teknik Industri, Universitas Katolik Parahyangan \\ Jl. Ciumbuleuit 94, Bandung 40141 \\ Email: carles@unpar.ac.id, paulina.ariningsih@unpar.ac.id, fransetiawan@unpar.ac.id
}

\begin{abstract}
Recent developments on the worldwide spread of Corona Virus Diseases-19 (COVID-19) show the vulnerability of human beings to pandemic risks in terms of biological, social, and economic factors. While human lives are the most important factor, a proposed solution dealing with pandemics should be sustainable which also includes other factors. Quarantines and physical distancing have been seen as effective ways to slow down the spread of COVID-19. We therefore propose a market scheduling model with multi-objectives to support physical distancing minimizing the number of people in a certain area in a given time (crowds) and minimizing the virus spread rates. An analytical model is proposed and solved for Bandung City. The results show some promising ideas on how to slow down the virus spread without compromising both health and economic objectives. The future potential research of the model is also presented.
\end{abstract}

Keywords: COVID-19, Market Scheduling, Mixed Integer Linear Programming, Optimization

\begin{abstract}
Abstrak
Perkembangan terkini pada penyebaran global Corona Virus Diseases-19 (COVID-19) menunjukkan kerentanan masyarakat terhadap risiko pandemi pada faktor biologis, sosial, dan ekonomi. Meskipun kesehatan merupakan faktor yang paling utama, solusi yang ditawarkan berkaitan dengan kejadian pandemi harus berkelanjutan yang melibatkan faktor-faktor lainnya. Karantina dan physical distancing telah terbukti menjadi langkah yang efektif untuk menekan penyebaran COVID-19. Oleh karena itu, kami mengusulkan model penjadwalan pasar yang multi-objektif untuk mendukung physical distancing dengan fungsi tujuan meminimasi jumlah orang pada area tertentu di waktu tertentu (kerumunan) dan meminimasi tingkat penyebaran virus. Model analitik yang diusulkan diselesaikan untuk Kota Bandung. Hasil menunjukkan beberapa kemungkinan yang menjanjikan untuk menekan penyebaran virus tanpa mengorbankan tujuan kesehatan dan ekonomi. Potensi untuk pengembangan model ini juga dipaparkan lebih lanjut.
\end{abstract}

Kata kunci: COVID-19, Mixed Integer Linear Programming, Optimasi, Penjadwalan Pasar

\section{Introduction}

Human beings are multi-faceted creatures who thrive to survive in all terms of biological, social, and economic senses. In the wake of worldwide spread of COVID-19, governments and societies take measures such as quarantines and lockdowns to slow down the virus spread. Even though those measures are seen to be effective, they also increase unemployment rates which cannot be sustained in the long run.

Uribe-Sánchez et al. (2011) show the needs for dynamic mitigation strategies for influenza pandemics particularly after the observation of avian-to-human transmittable $\mathrm{H} 5 \mathrm{~N} 1$ virus that has been occurring in the Asia, the Pacific, Africa, Europe and the Near East regions. They propose a predictive decision- 
aid methodology simulating the virus evolution and population dynamics during the outbreak.

However, it has been investigated that the COVID-19 virus is a human-to-human transmittable virus that forces all leaders to take a variation of lockdowns. Subsequently, governments then ease those measures into somewhat relaxed measures called "new normal". Required washing hands, wearing masks, and reduced capacity of public places which include markets are some of those relaxed measures. In May 30, 2020, Ridwan Kamil, the Governor of West Java had announced indicators and parameters for "new normal" practices for West Java Province through Peraturan Gubernur (PERGUB) JABAR Nomor 46/2020 (Simbolon, 2020) which also describes the micromanaging of these practices in Municipal levels including the Greater Bandung Area. This area includes several districts: Bandung City, Bandung Municipal, Cimahi City, Bandung Barat Municipal. Among those areas, Bandung Barat Municipal is the first area to apply "new normal" while the rest will apply it after the level of contagiousness of the area is on the lower level. Therefore, the social arrangement of the new normal shall be managed properly in several public aspects including economy. Without loss of generality, we will solve the problem for Bandung City due to lack of data in the other Municipals.

A large number of Indonesian households are going to traditional (wet) markets for their groceries. It is estimated that $82.3 \%$ stores in Indonesia are located in traditional wet markets (Sarinastiti, 2018). Additionally, some households do their groceries daily which increase their risks to the virus exposures. Close interaction in traditional markets may cause new contagious clusters (Atika, 2020). At the time this article is written, Indonesian Traditional Market Association had noted 37 cases of infected traditional market vendors in West Java Province (Atika, 2020). The Ministry of Trade decree No 12/2020 about complete operational requirements for trading activities provides health protocols in the traditional (wet) market. Some of these protocols are to limit the operational visit time and the maximum number of visitors down to $30 \%$ of the number of visitors in the normal condition (before COVID-19 pandemic) (Novika, 2020). The protocols include the application of physical distancing approximately $1.5 \mathrm{~m}$ from each other including with the sellers.

It is however difficult to apply these health protocols in the traditional (wet) market. Deputy IV of the presidential staff office for information and Political Communication admits that the government has difficulties in applying health protocol in the markets. One of the health protocols that is always violated is social distancing (Satrio, 2020). It is therefore our interests to limit the people's movements and to limit the number of people's concentration in a certain area in a given time. In doing so, the virus spread can be contained. This idea of limiting movements and concentration of people leads to the need of market scheduling.

We believe that the market's opening days should be scheduled while maintaining to fulfill the people's needs for their groceries and to keep businesses open. However, the objectives are not solely for business but also to slow down the virus spread. This idea also stems from Indonesian past times where markets are open only on certain days such as Sunday Market, Friday Market, Wednesday Market, etc.

A mathematical modeling for vaccination scheduling has been introduced by Röst \& Knipl (2011) during influenza pandemic outbreaks. They model the strategies for age specific transmission of H1N1 Virus. To date, however, the vaccination for COVID-19 virus is not yet available. It is therefore necessary to model this market scheduling in attempt to slow down the spread, mitigating its impact to both societal and economic factors. We develop a mixed integer linear programming model to schedule the market's opening days in aim to balance multiple objectives.

The remaining of this paper consists of the following sections. Problem formulation will be provided in Section 2 which also includes the mathematical model. In Section 3, Computational results are presented solving for Bandung City. The paper is then concluded in Section 4 with some recommendations for future research.

\section{Methodology}

The problem of market scheduling can be described as follows. 
The parameters of the problems are as follows:

$D=$ number of days

$M=$ number of markets

$K=$ number of kelurahan (urban-village)

$c_{k m}=$ distance from kelurahan $k$ to market $m$

$n_{k}=$ number of households in kelurahan $k$

$\eta_{m}=$ capacity of market $m$

$\pi_{m}=$ spread rate in market $m$ which is defined as the number of new positives cases divided by the number of cured cases (Rnaught).

The problem is to determine the following decision variables:

$X_{m d}=1$ if market $m$ is opened in day $d$ and zero otherwise

$Y_{k m d} \geq 0$ denotes the number of households $k$ assigned to market $m$ in day $d$.

Multiple objectives are designed to show tradeoffs among multiple factors:

1. Minimize the number of markets opened,

$$
\sum_{m=1}^{M} \sum_{d=1}^{D} X_{m d}
$$

2. Minimize total distance,

$$
\sum_{k=1}^{K} \sum_{m=1}^{M} \sum_{d=1}^{d} c_{k m} Y_{k m d}
$$

3. Minimize the spread rate,

$$
\sum_{k=1}^{K} \sum_{m=1}^{M} \sum_{d=1}^{D} \pi_{m} Y_{k m d}
$$

4. Minimize the concentration rate in a market in a given time,

$$
\frac{1}{\pi_{m}} \cdot \sum_{m=1}^{M} \sum_{d=1}^{D}\left(\sum_{k=1}^{K} Y_{k m d}-\eta_{m} X_{m d}\right)
$$

The first objective function shows that the total number of market's opening is minimized. In doing so, the movements of people are also minimized. The second objective function is meant to minimize the total distance travelled by all household in Bandung City. Minimizing the spread rate is accomplished in the third objective function, where we are interested to assigned as much as possible households to markets located in the low R-naught areas. The concentration of people in a given time in a certain market is also minimized in the fourth objective function. We are interested to maximize the slack (unused) market capacity attempting to make sure that a small number of people is concentrated in markets with high numbers of R-naught.

The following constraints are also introduced in the model:

1. A market may be opened or not within a week period,

$$
\sum_{d=1}^{D} X_{m d} \geq 0, \forall m
$$

2. A household can only be assigned to a market if it is opened,

$$
Y_{k m d} \leq n_{k} X_{m d}, \forall k, m, d
$$

3. All households must be able to do their groceries,

$$
\sum_{m=1}^{M} \sum_{d=1}^{D} Y_{k m d}=n_{k}, \forall k
$$

4. A number of people assigned to a market is limited to its capacity,

$$
\sum_{k=1}^{K} Y_{k m d} \leq \eta_{m}, \forall m, d
$$

Equation 5 makes sure that a market may be opened or not within a week period, that is if households are assigned to the market then the market must be opened. Bear in mind that decision makers are still able to adapt this constraint if it is necessary to make sure that all markets are opened at least once a week. That way, sellers can still do their businesses at least once a week during pandemic or relaxed lockdowns. Equation 6 shows that a household can only be assigned to a market if the market is opened in a given day. The fulfillment constraint in Equation 7 suggests that all households must be able to do their groceries in the week period. In this formulation, we assume that a household will do its groceries once per week. Again, a generalization of this constraint is still possible if there exists categorization of households. Equation 8 constraint suggests that a number of people assigned to a market is limited by its capacity.

The resulting model is a multi-objective mixed linear programming where each objective can be weighted by $\omega_{1}, \omega_{2}, \omega_{3}$ and $\omega_{4}$ respectively which values are the decision 
maker's choice. We suggest that the order of importance is as followed: Equation 3, Equation 4, Equation 1 and Equation 2. We focus on the importance of minimizing crowds in markets and minimizing the number of open markets in accordance with physical distancing policies. In this research, there is no upper bound for weights, the minimum or lower bound is 0 . The non-limitation on the upper bound is selected to give a greater flexibility of the decision maker.

\section{Results and Discussions}

The model is implemented to the data of Bandung City. The detailed data of the market is seen on Table 1 based on the data from Indonesian Statistical Bureau 2020. The geographical location for each market in Bandung City is shown in Figure 1. The city has 28 wet markets which provide groceries for households according to Indonesian Statistics Agency (Badan Pusat Statistik/BPS, 2020). The parameter of $\pi_{m}$ is estimated based on the concept of R0 or R-naught which shows the comparison of rate of positive cases with rate of healing cases. The concept of $R$-naught is widely known to show the contagiousness of a certain epidemic in a certain population (Breban et.al, 2007). Therefore, the estimation of $\pi_{m}$ is calculated based on the positive and cured cases in Bandung City case from March 2020 to June 2020 which is published in the official website of Bandung COVID Center in June 16, 2020.

Meanwhile the altitude and latitude data are derived from the center of gravity of each market as shown in the Google Map. We estimate the daily capacity of each market using following assumptions:

- Each household is represented by one shopper at a time,

- Each household goes to a market once in a week,

- Because of the minimum kiosk size is $1 \times 1.5$ square meters, each kiosk at a time can only be visited by one shopper,

- Each shopper spends 5 minutes in a kiosk,

- Time windows of the market is six hours a day,

- All kiosks are in service during the market's time window.

Amongst all markets in Bandung, it is known that the largest capacity market belongs to Pasar Baru, while the smallest capacity is in Pasar Gempol. We exclude two markets because the number of kiosks in Pasar Buah Batu and Saueran are unknown according to data from the City's Information and Documentation Management Officer (Pejabat Pengelola Informasi dan Dokumentasi, 2016).

Bandung City is divided into 151 different kelurahan (urban-villages) which are spread over 16 kecamatan (sub-districts). Each kelurahan has different number of households, where a sample data can be seen in Table 2 . We collect the number of households' data for each kelurahan from BPS data of 2020. While the attitude and latitude center of gravity from each kelurahan are taken from google map data. Based on the data, Kelurahan Margasari has the largest number of households (12478 households), while Kelurahan Citarum has the smallest number of households (853 households).

We estimated the distance from each kelurahan to each market based on Euclidian distances. Euclidian distances measure the straight-line distance from the center of gravity of each kelurahan to the center of gravity of each market. The Euclidian distances are calculated based on the altitude and latitude and then converted to kilometers $(1$ degree $=$ $111.322 \mathrm{~km})$. The sample of data distance from kelurahan to markets is depicted in Table 3. The data shows that roughly the distance between kelurahan and market is within $1-13$ $\mathrm{km}$.

We use AMPL (A Mathematical Programming Language) to obtain the solution from the model and the available data. The analytical solution is generated for the developed mixed integer linear programming with CPLEX computational software. For computational experiments, we use some values of weight to the first objective functions $\left(\omega_{1}\right)$ and for the fourth objective function $\left(\omega_{4}\right)$. These values are varied in order to examine the behavior of different objective functions. By design, we see that Objective Function (OF) 1 and 2 in (1) and (2) have a similar meaning to minimize the opening cost of the market. Meanwhile, OF 3 and 4 in (3) and (4) also have similar objectives to reduce the contagiousness effect of Covid-19. 


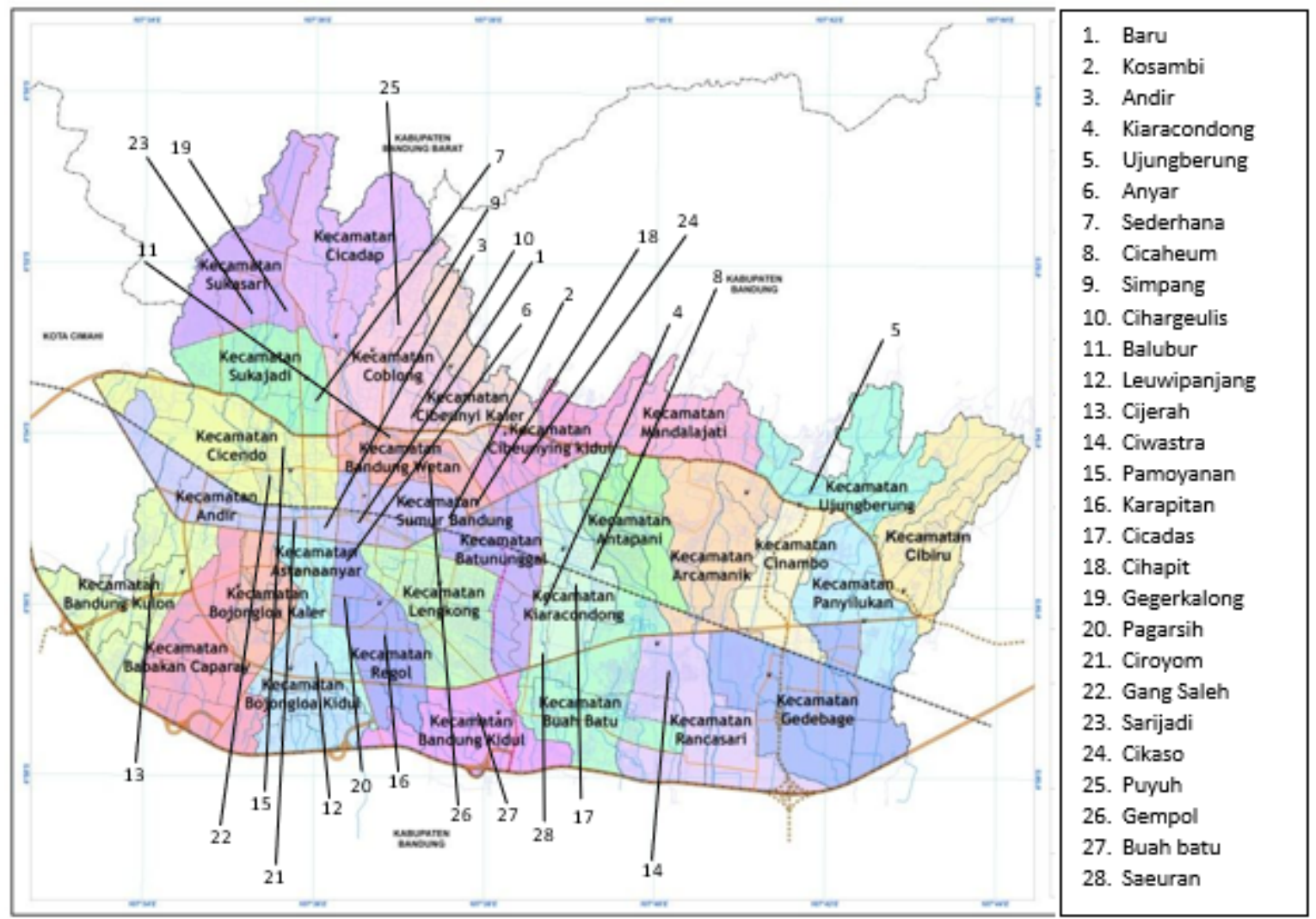

Figure 1. Location of markets in Bandung City Map

Table 1. Sample of Market Data in Bandung City Area

\begin{tabular}{|c|c|c|c|c|c|c|c|}
\hline Market name & $m$ & Sub-District & $\begin{array}{r}\text { Number } \\
\text { of kiosks }\end{array}$ & $\begin{array}{c}\text { Estimated } \\
\text { Daily } \\
\text { Capacity } \\
\text { (household) }\end{array}$ & $\begin{array}{c}\text { Estimated } \\
\pi_{m}\end{array}$ & Attitude & Latitude \\
\hline Baru & 1 & Andir & 4672 & 336384 & 2.75 & -6.92 & 107.60 \\
\hline Kosambi & 2 & Sumur Bandung & 1376 & 99072 & 1.50 & -6.92 & 107.62 \\
\hline Andir & 3 & Andir & 1895 & 136440 & 2.75 & -6.92 & 107.59 \\
\hline Kiaracondong & 4 & Kiaracondong & 1058 & 76176 & 2.57 & -6.93 & 107.64 \\
\hline Sederhana & 5 & Sukajadi & 1520 & 109440 & 1.25 & -6.89 & 107.60 \\
\hline Cicaheum & 6 & Kiaracondong & 566 & 40752 & 2.57 & -6.90 & 107.65 \\
\hline$\cdots$ & $\cdots$ & $\cdots$ & $\cdots$ & $\cdots$ & $\cdots$ & $\cdots$ & $\cdots$ \\
\hline Gang Saleh & 22 & Cicendo & 68 & 4896 & 1.58 & -6.91 & 107.59 \\
\hline Sarijadi & 23 & Sukasari & 110 & 7920 & 2.00 & -6.87 & 107.57 \\
\hline Cikaso & 24 & $\begin{array}{c}\text { Cibeunying } \\
\text { Kidul }\end{array}$ & 159 & 11448 & 2.25 & -6.91 & 107.63 \\
\hline Puyuh & 25 & Coblong & 58 & 4176 & 3.14 & -6.90 & 107.62 \\
\hline Gempol & 26 & Bandung Wetan & 46 & 3312 & 2.00 & -6.90 & 107.61 \\
\hline Pasar Buah Batu & 27 & Bandung Kidul & 0 & 0 & 1.50 & -6.95 & 107.64 \\
\hline Pasar Saeuran & 28 & Batununggal & 0 & 0 & 2.25 & -6.96 & 107.62 \\
\hline
\end{tabular}


DOI: https://doi.org/10.26593/irsi.v9i2.4010.87-98

Table 2. Sample Data of Kelurahan in Bandung City Area

\begin{tabular}{|c|c|c|c|c|}
\hline Kelurahan & $\boldsymbol{k}$ & Number of households & Attitude & Lattitude \\
\hline Campaka & 1 & 5831 & -6.901 & 107.557 \\
\hline Ciroyom & 2 & 6433 & -6.915 & 107.584 \\
\hline Dungus Cariang & 3 & 6136 & -6.913 & 107.577 \\
\hline Garuda & 4 & 3538 & -6.915 & 107.576 \\
\hline$\ldots$ & & & & \\
\hline Citarum & 40 & 853 & -6.905 & 107.609 \\
\hline Tamansari & 41 & 7830 & -6.901 & 107.599 \\
\hline$\ldots$ & $\ldots$ & $\ldots$ & $\ldots$ & $\ldots$ \\
\hline Margasari & 63 & 12478 & -6.955 & 107.648 \\
\hline Sekejati & 64 & 7931 & -6.946 & 107.644 \\
\hline$\ldots$ & $\ldots$ & $\ldots$ & -6.902 & 107.689 \\
\hline Pasirwangi & 150 & 5144 & & 107.691 \\
\hline Pasirjati & 151 & 5369 & & \\
\hline & & & & \\
\hline
\end{tabular}

Table 3. Sample Data Distances between Kelurahan to Market in Bandung City Area

\begin{tabular}{|c|c|c|c|c|c|c|c|c|c|c|c|}
\hline \multirow{2}{*}{$\begin{array}{c}\text { Kelurahan } \\
(\mathbf{k})\end{array}$} & \multicolumn{10}{|c|}{ Market (m) } \\
\cline { 2 - 13 } & $\mathbf{1}$ & $\mathbf{2}$ & $\mathbf{3}$ & $\mathbf{4}$ & $\mathbf{5}$ & $\mathbf{6}$ & $\ldots$ & $\mathbf{2 5}$ & $\mathbf{2 6}$ & $\mathbf{2 7}$ & $\mathbf{2 8}$ \\
\hline 1 & 5.65 & 7.57 & 4.20 & 10.15 & 16.21 & 5.72 & $\ldots$ & 7.16 & 6.29 & 10.73 & 9.98 \\
\hline 2 & 2.37 & 4.33 & 0.82 & 6.88 & 13.18 & 2.40 & $\ldots$ & 4.62 & 3.58 & 7.37 & 6.76 \\
\hline 3 & 3.16 & 5.12 & 1.62 & 7.68 & 13.95 & 3.12 & $\ldots$ & 5.25 & 4.24 & 8.12 & 7.43 \\
\hline$\ldots$ & $\ldots$ & $\ldots$ & $\ldots$ & $\ldots$ & $\ldots$ & $\ldots$ & $\ldots$ & $\ldots$ & $\ldots$ & $\ldots$ & $\ldots$ \\
\hline 144 & 0.06 & 1.96 & 1.58 & 4.52 & 10.84 & 1.53 & $\ldots$ & 2.93 & 1.94 & 5.40 & 5.25 \\
\hline 145 & 1.06 & 0.90 & 2.63 & 3.47 & 9.80 & 2.14 & $\ldots$ & 2.52 & 1.79 & 4.67 & 4.85 \\
\hline 146 & 0.98 & 1.27 & 2.50 & 3.82 & 9.96 & 2.43 & $\ldots$ & 2.03 & 1.18 & 5.28 & 5.48 \\
\hline 147 & 9.90 & 7.99 & 11.49 & 5.74 & 1.03 & 10.78 & $\ldots$ & 8.16 & 8.94 & 7.97 & 9.78 \\
\hline 148 & 11.18 & 9.26 & 12.77 & 6.96 & 0.45 & 12.03 & $\ldots$ & 9.45 & 10.24 & 8.97 & 10.80 \\
\hline 149 & 8.71 & 6.84 & 10.28 & 4.82 & 2.46 & 9.70 & $\ldots$ & 6.80 & 7.62 & 7.46 & 9.20 \\
\hline 150 & 9.54 & 7.68 & 11.10 & 5.65 & 1.95 & 10.54 & $\ldots$ & 7.56 & 8.42 & 8.20 & 9.97 \\
\hline 151 & 9.79 & 7.93 & 11.36 & 5.86 & 1.71 & 10.78 & $\ldots$ & 7.84 & 8.69 & 8.36 & 10.13 \\
\hline
\end{tabular}

Without loss of generality, $\omega_{1}$ and $\omega_{4}$ are selected as the representatives of these intentions. The experimental values of these weights and their results can be shown in Table 4 and 5.

From Table 4 and 5, it may clearly be seen that the increment of $\omega_{1}$ and $\omega_{4}$ has an increase to the value of the second and third objective functions. We assign the value of $\omega_{1}$ from 1000 to 10000000 in Table 4 to give a description on the extreme performance of $\omega_{1}$ in several different scenarios. For the same argument, we assign the value of $\omega_{4}$ from 0.01 to 10 since the value of $\omega_{4}$ has become denominator on OF 4. 
From Table 4 and 5 we can see that the higher weight of $\omega_{1}$ the higher value of objective function 4 which is in contradict with the relationship of $\omega_{4}$ and the Objective Function 4. It means that when a market is scheduled to open, we may reduce the contagiousness rate. Meanwhile if we concentrate more in a certain market, the demand needs to be covered will also be higher. It is obvious that the number of opened markets is in contrast with the average opening frequency.

Figure 2 and 3 depicts the trade-offs between Objective Function (OF) 1 and OF 4 as the value of $\omega_{1}$ and $\omega_{4}$ increases.

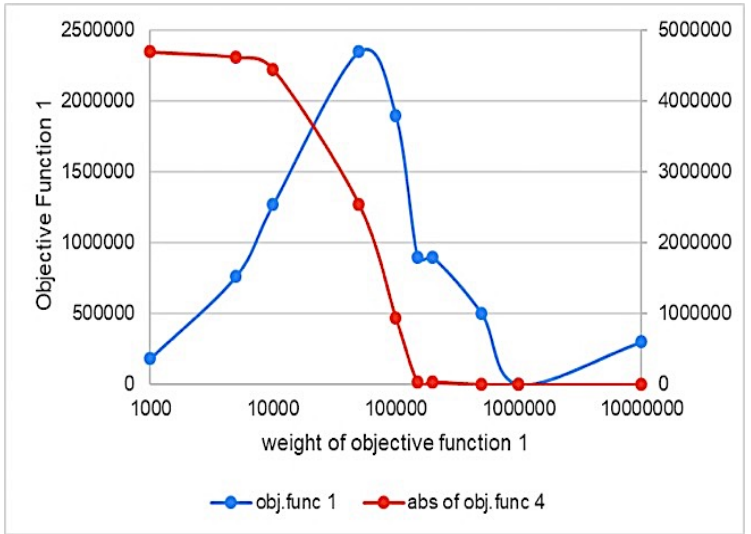

Figure 2. Impact of $\omega_{1}$ towards OF 1 and OF4

From Figure 2, we may see that the steady situation for OF 4 is realized when $\omega_{1} \geq$ 100000. The number is selected arbitrarily to show decision maker's preference on the objective function. Contradictory values of OF 1 and OF 4 appear for $1000 \leq \omega_{1}<100000$. Meanwhile there is an odd phenomenon for $\omega_{1}$ $=10000000$ since it is shown a slight increase for OF 1.

Figure 3 shows that the Objective Function 1 and Objective Function 4 are in reverse especially when $\omega_{4}>1$. There is no significant impact of $\omega_{4}$ towards OF 1 and OF 4 when the $\omega_{4} \leq 1$.

We are also interested in the situation if the government wants to open all the market to maintain the economic stability continuation of all sellers in Bandung City. Therefore, we adapt a change to the model for the first constraint (Equation 5) into the following constraint:

$$
\sum_{d=1}^{D} X_{m d} \geq 1, \forall m
$$

By changing the first constraint (Eq. 5) to Eq. 9, we force all markets to be opened at least once in a week. Again, we conduct computational experiments using the same fashion as before. The experimental values of the weight of the first and fourth objective functions and their result are shown in Table 6 and 7.

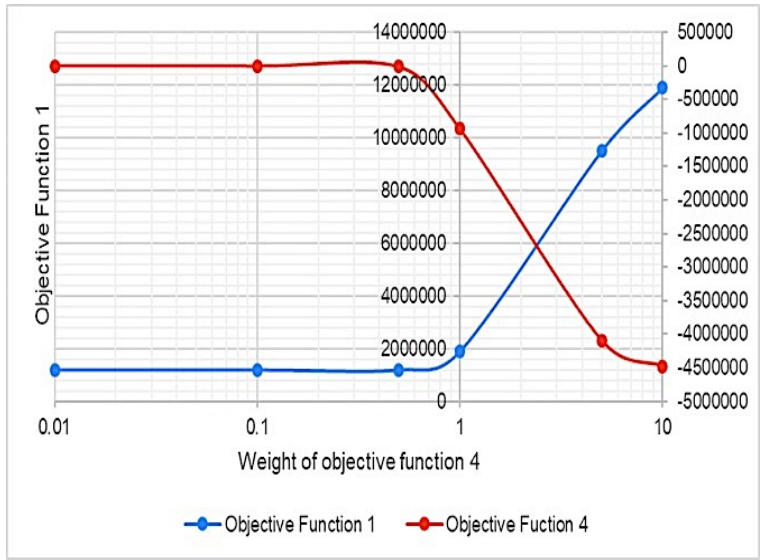

Figure 3. Impact of $\omega_{4}$ towards OF 1 and OF4

From Table 6 and 7, as well as Figure 4 and 5, we can see that very similar phenomenon happens in the result of the first and second scenario. However, all market are opens in a week as a consequence of the replacement of Eq. 5 with Eq. 9.

From the Figure 4 we may see that the steady situation for OF 1 and OF 4 may happen when $\omega_{1} \geq 100000$. The contradictory values of OF 1 and OF 4 appear for 1000 $\leq \omega_{1}<100000$.

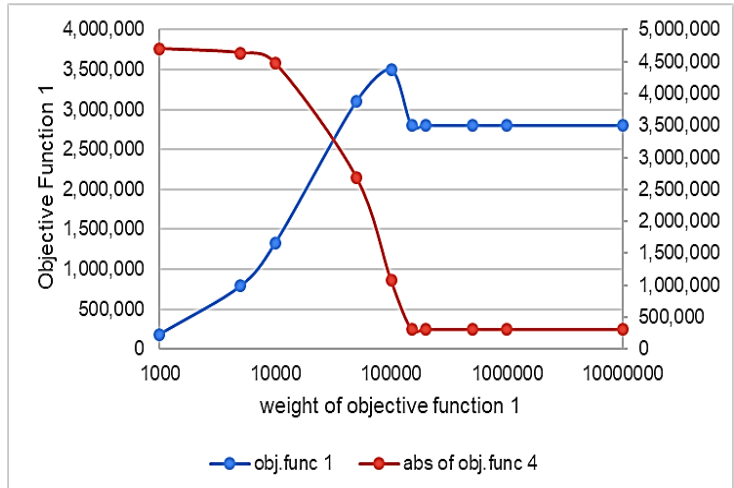

Figure 4. Impact of $\omega_{1}$ towards OF 1 and OF4 for scenario 2 
DOI: https://doi.org/10.26593/irsi.v9i2.4010.87-98

Table 4. The experimental values of the weight for the first objective function

\begin{tabular}{|c|c|c|c|c|c|c|c|}
\hline No & $\begin{array}{c}\text { Weight of } \\
\text { Objective } \\
\text { Function } \\
\text { (OF) } 1 \\
\left(\omega_{1}\right)\end{array}$ & $\begin{array}{c}\text { Value of } \\
\text { Objective } \\
\text { Function } \\
1\end{array}$ & $\begin{array}{c}\text { Value of } \\
\text { Objective } \\
\text { Function } \\
2\end{array}$ & $\begin{array}{c}\text { Value of } \\
\text { Objective } \\
\text { Function } \\
3\end{array}$ & $\begin{array}{c}\text { Value of } \\
\text { Objective } \\
\text { Function } \\
4\end{array}$ & $\begin{array}{c}\text { The average } \\
\text { of market's } \\
\text { weekly } \\
\text { opening } \\
\text { frequency } \\
\end{array}$ & $\begin{array}{c}\text { Number } \\
\text { of opened } \\
\text { markets } \\
\text { in a week }\end{array}$ \\
\hline 1 & 1000 & 182000 & 1066930 & 1567630 & -4700810 & 6.50 & 26 \\
\hline 2 & 5000 & 765000 & 1103040 & 1525760 & -4623880 & 5.46 & 23 \\
\hline 3 & 10000 & 1270000 & 1111870 & 1526200 & -4456260 & 4.54 & 21 \\
\hline 4 & 50000 & 2350000 & 1354500 & 1479380 & -2550740 & 1.68 & 13 \\
\hline 5 & 100000 & 1900000 & 1531840 & 1538030 & -942574 & 0.68 & 10 \\
\hline 6 & 150000 & 900000 & 1767060 & 1617500 & -37853 & 0.32 & 8 \\
\hline 7 & 200000 & 900000 & 1767060 & 1617500 & -37853 & 0.32 & 8 \\
\hline 8 & 500000 & 500000 & 2706360 & 1862610 & -3711 & 0.18 & 4 \\
\hline 9 & 1000000 & 300000 & 3471880 & 2174430 & -2088 & 0.11 & 2 \\
\hline 10 & 10000000 & 300000 & 3471880 & 2174430 & -2088 & 0.11 & 2 \\
\hline
\end{tabular}

Table 5. The experimental values of the weight for the fourth objective function

\begin{tabular}{|c|c|c|c|c|c|r|r|}
\hline No & $\begin{array}{c}\text { Weight of } \\
\text { Objective } \\
\text { Function } \\
(\mathbf{O F}) \mathbf{4} \\
\left(\omega_{4}\right)\end{array}$ & $\begin{array}{c}\text { Value of } \\
\text { Objective } \\
\text { Function } \\
\mathbf{1}\end{array}$ & $\begin{array}{c}\text { Value of } \\
\text { Objective } \\
\text { Function } \\
\mathbf{2}\end{array}$ & $\begin{array}{c}\text { Value of } \\
\text { Objective } \\
\text { Function } \\
\mathbf{3}\end{array}$ & $\begin{array}{c}\text { Value of } \\
\text { Objective } \\
\text { Function } \\
\mathbf{4}\end{array}$ & $\begin{array}{c}\text { The average } \\
\text { of market's } \\
\text { weekly } \\
\text { opening } \\
\text { frequency }\end{array}$ & $\begin{array}{c}\text { Number } \\
\text { of opened } \\
\text { markets } \\
\text { in a week }\end{array}$ \\
\hline 1 & 0.01 & 1200000 & 1611380 & 1429520 & -289 & 0.43 & 9 \\
\hline 2 & 0.10 & 1200000 & 1608060 & 1432890 & -2977 & 0.43 & 9 \\
\hline 3 & 0.50 & 1200000 & 1608060 & 1432890 & -14886 & 0.43 & 9 \\
\hline 4 & 1.00 & 1900000 & 1531840 & 1538030 & -942574 & 0.68 & 10 \\
\hline 5 & 5.00 & 9500000 & 1232090 & 1668090 & -4098040 & 3.39 & 16 \\
\hline 6 & 10.00 & 11900000 & 1264660 & 1791350 & -4479860 & 4.25 & 17 \\
\hline
\end{tabular}

Table 6. The experimental values of the weight for the first objective function (scenario 2)

\begin{tabular}{|c|c|c|c|c|c|c|c|}
\hline No & $\begin{array}{c}\text { Weight of } \\
\text { Objective } \\
\text { Function } \\
(\text { OF) } \mathbf{1} \\
\left(\boldsymbol{\omega}_{\mathbf{1}}\right)\end{array}$ & $\begin{array}{c}\text { Value of } \\
\text { Objective } \\
\text { Function } \\
\mathbf{1}\end{array}$ & $\begin{array}{c}\text { Value of } \\
\text { Objective } \\
\text { Function } \\
\mathbf{2}\end{array}$ & $\begin{array}{c}\text { Value of } \\
\text { Objective } \\
\text { Function } \\
\mathbf{3}\end{array}$ & $\begin{array}{c}\text { Value of } \\
\text { Objective } \\
\text { Function } \\
\mathbf{4}\end{array}$ & $\begin{array}{c}\text { The average of } \\
\text { market's } \\
\text { weekly } \\
\text { opening } \\
\text { frequency }\end{array}$ & $\begin{array}{c}\text { Number of } \\
\text { opened } \\
\text { markets in } \\
\text { a week }\end{array}$ \\
\hline 1 & 1000 & 184000 & 1066930 & 1567630 & -4700810 & 6.57 & 26 \\
\hline 2 & 5000 & 790000 & 1085550 & 1546990 & -4634600 & 4.75 & 26 \\
\hline 3 & 10000 & 1330000 & 1099960 & 1542490 & -4470570 & 2.21 & 26 \\
\hline 4 & 50000 & 3100000 & 1161230 & 1549960 & -2690930 & 1.25 & 26 \\
\hline 5 & 100000 & 3500000 & 1309110 & 1600780 & -1072900 & 1.00 & 26 \\
\hline 6 & 150000 & 2800000 & 1359940 & 1627020 & -311165 & 1.00 & 26 \\
\hline 7 & 200000 & 2800000 & 1359940 & 1627020 & -311165 & 1.00 & 26 \\
\hline 8 & 500000 & 2800000 & 1359940 & 1627020 & -311165 & 1.00 & 26 \\
\hline 9 & 1000000 & 2800000 & 1359940 & 1627020 & -311165 & -311165 & 26 \\
\hline 10 & 10000000 & 2800000 & 1359940 & 1627020 & & 26 \\
\hline
\end{tabular}


Table 7. The experimental values of the weight for the fourth objective function (scenario 2)

\begin{tabular}{|c|r|r|r|c|c|r|r|}
\hline No & $\begin{array}{c}\text { Weight of } \\
\text { Objective } \\
\text { Function } \\
(\mathbf{O F}) \mathbf{4} \\
\left(\boldsymbol{\omega}_{\mathbf{4}}\right)\end{array}$ & $\begin{array}{c}\text { Value of } \\
\text { Objective } \\
\text { Function }\end{array}$ & $\begin{array}{c}\text { Value of } \\
\text { Objective } \\
\text { Function } \\
\mathbf{2}\end{array}$ & $\begin{array}{c}\text { Value of } \\
\text { Objective } \\
\text { Function } \\
\mathbf{3}\end{array}$ & $\begin{array}{c}\text { Value of } \\
\text { Objective } \\
\text { Function } \\
\mathbf{4}\end{array}$ & $\begin{array}{c}\text { The average of } \\
\text { market's } \\
\text { weekly } \\
\text { opening } \\
\text { frequency }\end{array}$ & $\begin{array}{c}\text { Number of } \\
\text { opened } \\
\text { markets in } \\
\text { a week }\end{array}$ \\
\hline 1 & 0.01 & 2800000 & 1391910 & 1587150 & -3010.58 & 1.00 & 26 \\
\hline 2 & 0.1 & 2800000 & 1391910 & 1587150 & -30105.8 & 1.00 & 26 \\
\hline 3 & 0.5 & 2800000 & 1389790 & 1589400 & -150767 & 1.00 & 26 \\
\hline 4 & 1 & 3500000 & 1309110 & 1600780 & -1072900 & 1.25 & 26 \\
\hline 5 & 5 & 10700000 & 1162130 & 1666960 & -4155190 & 3.82 & 26 \\
\hline 6 & 10 & 13000000 & 1203410 & 1823510 & -4522610 & 4.64 & 26 \\
\hline
\end{tabular}

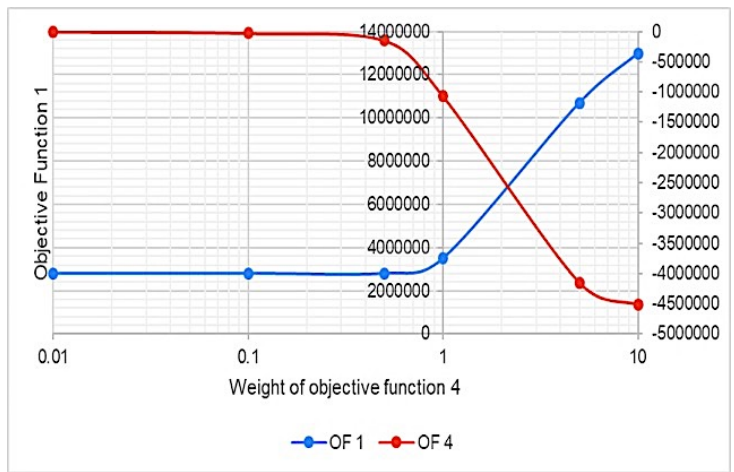

Figure 5. Impact of $\omega_{4}$ towards OF 1 and OF4 for scenario 2

We recommend to the City's Major to implement the result which gives the minimum spread of COVID-19 while keeping businesses open. In order to minimize the spread of COVID-19, we select the result of experimental value in table 4 (for the decision not to open all the markets) and from table 6 (for the decision to open all the markets) which provide the smallest value of OF 3 .

If the decision is to open some of the markets (scenario 1), then only 13 markets in the City will be opened to minimize the spread rate of COVID-19 with only market $1,2,7,11$, and 17 that will be opened every day. While if the decision is to open all the markets at least once in a week then markets $9,10,15,18,22$, $23,24,25,26,27$ and 28 will not be opened daily and the rest of markets are opened daily. The spread rate with the decision not to open all the markets is lower than the decision to open all the markets (1479380 compared to 1542490).

If the decision is to force all markets to be opened (scenario 2), the schedule that minimize the spread of COVID-19 can be shown in Table 9.
Table 8. Proposed market schedule for decision not to open all of markets

\begin{tabular}{|c|l|}
\hline Market & \multicolumn{1}{|c|}{ Opening } \\
\hline 1 & Everyday \\
\hline 2 & Everyday \\
\hline 3 & Mon \\
\hline 4 & Wed \\
\hline 5 & Wed, Fri \\
\hline 6 & Fri \\
\hline 7 & Everyday \\
\hline 8 & Wed \\
\hline 11 & Everyday \\
\hline 12 & Sat \\
\hline 13 & Wed, Thu, Fri \\
\hline 14 & Mon, Fri \\
\hline 17 & Everyday \\
\hline
\end{tabular}

However, to assure the economy continuation to the sellers, the City's Major may choose to open all markets with the schedule in Table 9. To implement the proposed solution in Table 9, there are several other considerations such as: the expiry of the farm products and the cost of operations. In the other hand, if the second scenario is decided to be implemented, the market that is not listed in Table 8 can be used to serve other economical purposes such as restaurant or other business supporting.

The model has shown the assignment of households' demand to markets by minimizing the distance and the spread. Each traditional (wet) market in Bandung has different characteristics and excellences. For example, Pasar Andir has been famous for its poultry products, while Pasar Cihapit has been famous for traditional snacks. Moreover, some markets have higher average prices than others. Therefore, opening or closing certain market would let consumers to expect different quality of groceries with the same prices. Dinas Pasar 
Bandung thus should make sure that the groceries have to meet minimum quality requirement and to keep standard prices among those markets.

Table 9. Proposed market schedule for the decision to open all of markets

\begin{tabular}{|c|l|}
\hline Market & \multicolumn{1}{|c|}{ Opening } \\
\hline 1 & Everyday \\
\hline 2 & Everyday \\
\hline 3 & Everyday \\
\hline 4 & Everyday \\
\hline 5 & Everyday \\
\hline 6 & Everyday \\
\hline 7 & Everyday \\
\hline 8 & Everyday \\
\hline 9 & Sun \\
\hline 10 & Fri \\
\hline 11 & Everyday \\
\hline 12 & Everyday \\
\hline 13 & Everyday \\
\hline 14 & Everyday \\
\hline 15 & Wed, Sat \\
\hline 16 & Everyday \\
\hline 17 & Everyday \\
\hline 18 & Tue \\
\hline 19 & Everyday \\
\hline 20 & Everyday \\
\hline 21 & Everyday \\
\hline 22 & Thu \\
\hline 23 & Tue, Wed, Sat \\
\hline 24 & Sat \\
\hline 25 & Mon \\
\hline 26 & Fri \\
\hline 27 & Sun \\
\hline 28 & Sun \\
\hline & \\
\hline & \\
\hline
\end{tabular}

\section{Conclusion}

In this article, we propose a multi-objective mixed integer linear programming for market scheduling in the situation for new normal in Bandung City. The model has positively generated optimum result for two scenarios: minimizing the market's opening; and making sure a market is open at least once in a week. Deeper analysis on the model has shown that there exists a tradeoff between objective function 1 and objective function 2 . This is in line with the principles of physical and social distancing.

The proposed model is implemented for the parameter situation of Bandung City with the estimation of R-naught from March 2020 to June 2020. However, the R-naught data may be varying after some time. Therefore, we suggest for better results to implement the model with the latest R-naught data.

In the proposed model it is assumed that there would not be a closing down of a market whenever a market becomes a new contagious cluster or other stochastic events. Furthermore, the proposed model is also assuming that there is similar time windows for all traditional market. Meanwhile, in reality, several markets such as Pasar Andir and Pasar Sederhana have longer time windows compare to others (ex. Pasar Cihapit). Whenever the decision maker shorten the time of windows, it is expected that more markets should be opened to meet all demands. For future potential research, it is suggested to develop a stochastic model of the system and to consider the impact of time windows on the market scheduling model.

\section{References}

Atika, S. (2020). Indonesian wet markets carry high risk of virus transmission, The Jakarta Post, [Online], Diakses dari: https://www.thejakartapost.com/news/2020/ 06/14/indonesian-traditional-markets-carryhigh-risk-of-virus-infection.html [2020, 16 Juni].

Breban R, Vardavas R, \& Blower S. (2007) Theory versus Data: How to Calculate R0?. PLOS ONE. 2(3), 1-4.

BPS (2020), Kota Bandung Dalam Angka 2020, Badan Pusat Statistika Indonesia.

Pejabat Pengelola Informasi dan Dokumentasi (PPID) Kota Bandung. (2016). Data Pasar Sekota Bandung PD. Pasar Bermartabat, PPID Kota Bandung, [Online], Diakses dari: https://ppid.bandung.go.id/knowledgebase/ data-pasar-sekota-bandung/ $[2020,12$ Juni].

Röst, G., Knipl, D. H. (2011). Modeling the Strategis for Age Specific Vaccination Scheduling During Influenza Pandemic Outbreaks. Mathematical Biosciences and Engineering. 8(1), 123-139.

Novika, S. (2020). Apa Saja Aturan Masuk ke Pasar Tradisional Selama New Normal?, [Online], Diakses dari: https://finance.detik.com/berita-ekonomibisnis/d-5040037/apa-saja-aturan-masukke-pasar-tradisional-selama-new-normal [2020, 18 Juni]. 
Sarinastiti, N. (2018). Deeper Look into Indonesian Consumers: Leveraging Routeto-Market Approach to Win the Market, White Paper: Snapart \& Accenture.

Satrio, A.D. (2020). Pemerintah Akui Kesulitan Terapkan Protokol Kesehatan di Pasar Tradisional, Okenews, [Online], Diakses dari:

https://nasional.okezone.com/read/2020/06/ 13/337/2229439/pemerintah-akui-kesulitanterapkan-protokol-kesehatan-di-pasartradisional [2020, 18 Juni].
Simbolon, H. (2020). Ridwan Kamil Terbitkan Peraturan Persiapan Adaptasi Kebiasaan Baru Jabar, [Online], Diakses dari: https://www.liputan6.com/regional/read/426 9249/ridwan-kamil-terbitkan-peraturanpersiapan-adaptasi-kebiasaan-baru-jabar [2020, 16 Juni].

Uribe-Sánchez, A., Savachkin, A., Santana, A., Prieto-Santa, D., \& Das, T. K. (2011). A Predictive Decision-Aid Methodology for Dynamic Mitigation of Influenza Pandemics. OR Spectrum, 33, 751-786. 
DOI: https://doi.org/10.26593/irsi.v9i2.4010.87-98

Halaman ini sengaja dikosongkan.

This page is intentionally left blank. 